\title{
Nutlet micromorphology and character evolution of Lappula species (Boraginaceae) and its systematic implications
}

\author{
Mostafa Ebadi ${ }^{* *}$ and Sedigheh Nikzat ${ }^{2}$
}

\begin{abstract}
Background: The macro/micro-morphology of nutlets in 11 species (and 22 accessions) of the Boraginaceae family was investigated using stereomicroscope and scanning electron microscopy to evaluate the taxonomic relevance of the traits. To evaluate the phylogenetic significance of the character evolution, phylogenetic analysis was carried out by comparing available DNA sequence data from GenBank with selected original nutlet data.

Results: The Rochelieae nutlets' shape varied from ovoid (ovoid, ovoid-triangular, and ovoid-rectangular) to pyramid. Six major patterns were recognized based on the nutlet ultrastructure characters. Rocheliae is characterized by a transition from "without appendage" to "with tubercles and prickles" on the nutlet disk, and also via a shift from "lack of prickles" to "glossy prickles".

Conclusions: The results show that the nutlet ultrastructure pattern of Rochelieae is systematically informative at the genus level, but not at the species level. Findings demonstrated that glochid is not an ancestral trait but is a synapomorphy and the transition to this trait occurred in the genus Lappula. The close boundary of nutlet microstructures between L. barbata and L. microcarpa has been discussed.
\end{abstract}

Keywords: Character evolution, Lappula, Micromorphology, Systematic

\section{Background}

Boraginaceae s.str. is a sub cosmopolitan family of flowering plants with nearly 90 genera and ca.1600 to 1700 species distributed globally. According to a molecular phylogeny study by Chacón et al. (2016), infrafamilial classification of Boraginaceae might fall within three Subfamilies (Echiochiloideae, Boraginoideae, Cynoglossoideae) and 10 tribes (Boragineae, Lithospermeae, Trichodesmeae, Lasiocaryeae, Asperugeae, Omphalodeae, Rochelieae, Craniospermeae, Myosotideae, Cynoglosseae). Tribe Rochelieae consists of approximately 207 species, and belongs to the subfamily Cynoglossoideae. According to Chacón et al. (2016), Rochelieae

\footnotetext{
${ }^{*}$ Correspondence: ebadi2023@gmail.com

${ }^{1}$ Department of Biology, Faculty of Sciences, Azarbaijan Shahid Madani

University, 53714-161 Tabriz, Iran

Full list of author information is available at the end of the article
}

can be divided into two subtribes including Eritrichiinae and Heterocaryinae. The genera Eritrichium, Hackelia, Lappula, Lepechiniella, and Rochelia, belong to the Eritrichiinae and the genera Heterocaryum, Suchtelenia, and Pseudoheterocaryum to sub-tribe Heterocaryinae (Chacón et al. 2016; Saadati et al. 2017). Three genera of subtribe Eritrichiinae (Eritrichium, Lepechiniella, and Lappula) are recognized as non-monophyletic lineage. Hackelia and Rochelia are comprised of monophyletic clades (Khoshsokhan-Mozaffar et al. 2018). The recent molecular phylogeny of the Rochelieae tribe provided by Khoshsokhan-Mozaffar et al. (2018) has indicated a well-supported clade. Hackelia and Rochelia are monophyletic while Lappula, Eritrichium, and Lepechiniella are not. Therefore, Lappula, as currently circumscribed, is polyphyletic (Khoshsokhan-Mozaffar et al. 2018). The genus Eritrichium is the largest genus of the tribe, with 71 species. The genus Lappula contains about 70 
species of annual, biennial perennial herbs distributed in Eurasia, Africa, North America, and Australia (Ovchinnikova 2005). Although Lappula has a cosmopolitan distribution, the center of diversity is in the Siberian and Irano-Turaniean provinces of the Holarctic kingdom (Ovchinnikova 2009). Initially, Lehmann (1818) circumscribed 15 species in Echinospermum Lehm. (Synonym of Lappula). Echinospermum was divided by de Candolle (1845) into three sections based on nutlet morphology as follow: Lappula, Sclerocaryum, and Homalocaryum. The taxonomical problems of Lappula were increased as the number of species in the genus began to expand. Consequently, the number of sections, subsections, and series seems to be widely varied upon what has been reported by different authors (Popov 1953; Riedl 1967). First off, Lehmann (1818) used nutlet characters in the systematics of Lappula and showed mericarp characters including mericarp shape and surface ornamentation to distinguish the species of this genus. Generally, regarding Boraginaceae, nutlet morphology provides valid systematic characters at various taxonomic levels, such as straight or incurved nutlet, a specialized form of emergence, the position of attachment scar, the distinctive form of prickles or glochids, and epidermal features of nutlets (Johnston 1937; Hilger 1985; Al-Shehbaz 1991; Riedl 1996; Långström and Chase 2002; Moon and Hong 2006; Selvi et al. 2006; Kahraman et al. 2011). In this study, we aimed to evaluate the nutlet morphological characters of several Iranian Lappula species and compare them to related genera in Rochelieae by scanning samples using electron microscopy. DNA sequence data and selected nutlet characters were examined to investigate the character evolution and phylogenetic relationships. The results will be discussed with a particular focus on Iranian species of Lappula and some related genera of the Rochelieae tribe.

\section{Methods \\ Morphological study}

The plants used in the present study were collected from their natural habitats in Iran and deposited in the Herbarium of Azarbaijan Shahid Madani University (ASMUH). Also, a small number of species were taken from herbarium specimens of FUMH (Ferdowsi University of Mashhad Herbarium). The list of voucher specimens and details of their locations were given in Table 1.

This study was carried out on nine species of tribe Rochelieae (covering four genera) and two species of tribes Asperugeae and Myosotideae as out-groups. Depending on the amount of material available, 10 nutlets of each taxon were investigated and scored for the standard descriptors in Table 2. The air dried nutlets (10 per each taxon and accession) were investigated for their shape, size, and other features using stereomicroscope

Table 1 List of sampled taxa, locality and their vouchers numbers

\begin{tabular}{|c|c|c|}
\hline Species (Pop. Code) & Locality & $\begin{array}{l}\text { Voucher } \\
\text { No. }\end{array}$ \\
\hline Lappula barbata (M.Bieb.) Gürke (m) & Tehran, Chalus road, Kooshk & ASMUH0020 \\
\hline L. barbata (c) & Mazandaran, Chalus, Delir vilage & ASMUH0021 \\
\hline L. barbata (ab) & Mazandaran, Noshahr, Kojur, Laregan & ASMUH0022 \\
\hline L. barbata (w) & Tehran, Tuchal & ASMUH0023 \\
\hline L. ceratophora (Popov) Popov & South Khorasan, south-west Sarayan & FUMH46077 \\
\hline L. microcarpa (Ledeb.) Gürke (b) & Mazandaran. Noor, Chamestan, Lavij & ASMUH0024 \\
\hline L. microcarpa (e) & Mazandaran, Neka, Hezarjerib & ASMUH0025 \\
\hline L. microcarpa (g) & Golestan, East of Golestan national park & ASMUH0026 \\
\hline L. microcarpa (i) & Mazandaran, Savadkooh, Veresk & ASMUH0027 \\
\hline L. microcarpa $(\mathrm{j})$ & Mazandaran, Polor to Rine & ASMUH0028 \\
\hline L. microcarpa (p) & Mazandaran, Noshahr, Kojur, & ASMUH0029 \\
\hline L. microcarpa (z) & North Khorasan, Chamanbid & ASMUH0030 \\
\hline L. microcarpa (a) & Tehran, Lavasan, Glucan & ASMUH0031 \\
\hline L. semiglabra (Ledeb.) Gürke & Khorasan Razavi, North of Gonabad & FUMH17236 \\
\hline L. sessiliflora (Boiss.) Gürke & Khorasan Razavi, East of Kashmar & FUMH26636 \\
\hline L. spinocarpus (Forssk.) Asch. ex Kuntze & South Khorasan, Birjand, Shahzile & FUMH30399 \\
\hline Pseudolappula sinaica (A.DC.) Asch. \& Schweinf & Tehran, Chalus road, Morod & ASMUH0032 \\
\hline Asperugo procumbens $L$ & Mazandaran, Damavand, Sarbandan & ASMUH0034 \\
\hline Heterocaryum rigidum A. DC & Tehran, Jajroad & ASMUH0035 \\
\hline Myosotis sylvatica Ehrh & Mazandaran, Sari, Sangdeh forest & ASMUH0036 \\
\hline Rochelia disperma (L. f) C. Koch & Tehran, Lavasan & ASMUH0037 \\
\hline
\end{tabular}


Table 2 Micromorphological characters of the nutlet in the studied taxa

\begin{tabular}{|c|c|c|c|c|c|c|c|c|c|}
\hline \multirow[t]{2}{*}{ Taxon } & \multicolumn{9}{|c|}{ Characters } \\
\hline & SN & $\mathrm{CL}$ & BPD & LS & AND & NGRN & TD & SE & PS \\
\hline L.microcarpa & 0 & 0 & 1 & 1 & 2 & 1 & 2 & 0 & 2 \\
\hline L. barbata & 0 & 1 & 0 & 1 & 2 & 2 & 2 & 0 & 2 \\
\hline L. semiglabra & 0 & 0 & 1 & 1 & 2 & 1 & 0 & 0 & 2 \\
\hline L.ceratophora & 4 & 0 & 0 & 1 & 1 & 0 & 0 & 1 & 0 \\
\hline L.spinocarpos & 4 & 0 & 0 & 1 & 1 & 0 & 0 & 1 & 0 \\
\hline L. sessiliflora & 3 & 2 & 2 & 1 & 2 & 1 & 3 & 0 & 1 \\
\hline R. disperma & 0 & 0 & 0 & 1 & 2 & 0 & 1 & 0 & 1 \\
\hline L. siniaca & 0 & 0 & 0 & 3 & 0 & 0 & 0 & 2 & 0 \\
\hline H. rigidum & 2 & 0 & 0 & 2 & 0 & 1 & 0 & 2 & 2 \\
\hline A. procumbens & 1 & 0 & 0 & 0 & 3 & 0 & 0 & 3 & 0 \\
\hline M. sylvatica & 5 & 0 & 0 & 1 & 1 & 0 & 0 & 4 & 0 \\
\hline
\end{tabular}

SN (shape of nutlet) including ovoid (0), semicircular (1), ovoid-rectangular (2), ovoid-triangular (3), pyramid (4), ellipse (5); CL (center line of nutlet) including absent (0), prominent with glochid (1), prominent with tubercles (2); BPD (base surface of prickles on desk) including lack of prickles (0), glabrous (1), verrucose (2); LS (Lamella status) including thread like (0), glossy (1), bumpy with verrucate (2), interrupt (3); AND (Appendage on nutlet desk) including papilla -verrucose (0), without appendage (1), with tuberculate and prickles (2), dome-shape papilla (3); NGRN (number of glochid row on nutlet edge) including lack of glochids (0), 1-row (1), 2-row. outer ones in a regular row (2); TD (tubercles on desk) including without spin (0), 2-3 spines (1), 4-5 spines (2), 5 spines (3); SE (surface emergence) including stellareaculeate (0), veruucose-subverrucose (1), papilla- verrucose (2), Papilla (3), nonexpressiate (4); PS (prickles surface) including lack of prickles (0), verrucose (1), glossy (2)

(Dino-Lite) using the DinoCapture eye and DinoCapture 2.0 Software (Electronics Corporation).

To observe nutlets under SEM, they were mounted (two per each taxon and accession) onto standard aluminum stubs using double-sided adhesive tape and then photographed using a PHILIPS / FEI XL 20 Scanning Electron Microscope at $15 \mathrm{kV}$ voltages. The measurements were based on 15-20 evaluations from each specimen.

The terminology used for describing the nine qualitative characters is in line with (Ma et al. 2010; Selvi et al. 2011; Yu et al. 2012; Hilger 2014). The very relevant traits were the shape of nutlet, the centerline of its shape, the base surface of prickles on the desk, lamella status, appendage on nutlet desk, the number of glochid row on nutlet edge, tubercles on a desk, prickles surface, and surface emergence (nutlet ultrasculpture) (Table 2).

Nutlet epidermal feature and its surface ornamentation (using SEM) are of diagnostic value in genera/species delimitation (Boyd 2002). The body of literature revealed their importance for delineating evolutionary pathways in the Boraginceae including Eritrichieae (Ovczinnikova 2007; Ovchinnikova 2008), Cynoglosseae and Eritrichieae (Hilger 2014), Microula (Yu et al. 2012), Cynoglossum L. (Akçin 2007), Lithospermum L. (Weigend et al. 2009), Onosma L. (Akcin 2008; Binzet and Akçin 2009), Lappula (Ma et al. 2010). Various nutlet traits were described and defined for these taxa. Reviewing the literature about our specimens paved the way for screening the final selected traits. For example, the traits related to the ornamentation of nutlet surface (states tuberculate and stellare-aculte of surface emergence) were defined according to (Ovchinnikova 2009) that studied the fruits of the Eritrichieae tribe. Moreover, the status of glochid and anchor was of great favor due to its significance concerning the Rochelieae tribe and particularly the Lappula genus. They were defined according to the study by (Ma et al. 2010) on nutlet dimorphism of the Lappula genus.

Finally, investigating the ontogeny and systematic importance of the fruits of Cynoglosseae and Eritrichieae (Hilger 2014) helped us achieving desirable characters and their status. These characters were scored as binary variables and numerical values, and then they were standardized and prepared for the following analysis.

The data were analyzed and examined by PCA, and WARD dendrogram using PAST software to study decimation of L. microcarpa and L.barbata species. Due to high morphological similarities between $L$. microcarpa and L.barbata, the Flora of Iran (Nasseh and Joharchi 2017) and Flora Iranica (Riedl 1996) were used for discerning them from each other.

\section{Phylogenetic analysis and tracing character evolution}

The sequences for the internal transcribed spacer (ITS) region were obtained from GenBank (Table 3). Based on Weigend et al. $(2009,2013)$ and Gottschling et al. (2014), the nuclear ribosomal DNA internal transcribed spacer (ITS), as well as the chloroplast (cp) DNA regions tRNALeu (trnL) gene and trnL-trnF intergenic spacer, are appropriate for studying the phylogenetics (phylogeny) of 
Table 3 List of taxa used in phylogenetic analysis with their GenBank accession numbers

\begin{tabular}{|c|c|c|}
\hline Taxon & $\begin{array}{l}\text { Tribe (based on } \\
\text { Chacón et al. 2016) }\end{array}$ & $\begin{array}{l}\text { GenBank } \\
\text { accession } \\
\text { number }\end{array}$ \\
\hline Heterocaryum macrocarpum & Rochelieae & AB758300.1 \\
\hline Heterocaryum szovitsianum & Rochelieae & AB758298.1 \\
\hline Heterocaryum subsessile & Rochelieae & KU927721.1 \\
\hline Heterocaryum rigidum * & Rochelieae & AB758299.1 \\
\hline Suchtelenia calycina (1) & Rochelieae & LC194913.1 \\
\hline Suchtelenia calycina (2) & Rochelieae & LC194912.1 \\
\hline Lappula balchaschensis & Rochelieae & JX976776.1 \\
\hline Lappula anocarpa & Rochelieae & JX976775.1 \\
\hline Lappula intermedia & Rochelieae & JX976785.1 \\
\hline Lappula patula & Rochelieae & AB758305.1 \\
\hline Lappula stricta & Rochelieae & JX976798.1 \\
\hline Lappula occidentalis & Rochelieae & KU927723.1 \\
\hline Lepechiniella wendelboi & Rochelieae & AB758314.1 \\
\hline Eritrichium rupestre & Rochelieae & KU927644.1 \\
\hline Eritrichium thymifolium & Rochelieae & JX976807.1 \\
\hline Eritrichium canum & Rochelieae & KU927710.1 \\
\hline Eritrichium splendens & Rochelieae & JQ388501.1 \\
\hline Eritrichium villosum & Rochelieae & JQ388502.1 \\
\hline Eritrichium pectinatociliatum & Rochelieae & KU927713.1 \\
\hline Eritrichium aretioides & Rochelieae & KU927709.1 \\
\hline Eritrichium nanum & Rochelieae & JQ388499.1 \\
\hline Hackelia micrantha & Rochelieae & JQ388504.1 \\
\hline Hackelia deflexa (1) & Rochelieae & JX976808.1 \\
\hline Hackelia deflexa (2) & Rochelieae & KU927716.1 \\
\hline Hackelia revoluta & Rochelieae & KF849119.1 \\
\hline Hackelia diffusa & Rochelieae & JQ388503.1 \\
\hline Rochelia macrocalyx & Rochelieae & AB564700.1 \\
\hline Rochelia bungei & Rochelieae & AB564695.1 \\
\hline Rochelia disperma* & Rochelieae & LC410071.1 \\
\hline Lappula ceratophora* & Rochelieae & AB758301.1 \\
\hline Lappula semiglabra* & Rochelieae & AB758306.1 \\
\hline Lappula spinocarpos* & Rochelieae & AB758309.1 \\
\hline Lappula sinaica* & Rochelieae & LC410061.1 \\
\hline Lappula sessiliflora* & Rochelieae & LC410059.1 \\
\hline Lappula microcarpa* & Rochelieae & JX976788.1 \\
\hline Lappula barbata* & Rochelieae & LC410054.1 \\
\hline Asperugo procumbens* & Asperugeae & AB758290.1 \\
\hline Myosotis sylvatica* & Myosotideae & AB989064.1 \\
\hline
\end{tabular}

*The species used for character evolution

the Boraginales at different taxonomic levels. Given the sequences deposited in the gene bank, we reconstructed the phylogenetic tree using ITS $1,5.8 \mathrm{~S}$ rRNA, ITS 2 , of the nuclear region.

To optimally show the intra-tribe relationship, the general topology of the phylogenetic tree was performed on the Phylogeny.fr platform (Fig. 2a) following bellow steps: (1) sequences were aligned via MUSCLE (v3.8.31) configured for the highest accuracy; (2) ambiguous regions were removed with Gblocks (v0.91b); (3) the phylogenetic tree was reconstructed using the maximum likelihood method implemented in the PhyML program (v3.1/3.0 aLRT) (4) the HKY85 substitution model was selected assuming an estimated proportion of invariant sites (of 0.435) and 4 gamma-distributed rate categories to account for rate heterogeneity across sites (the gamma shape parameter was estimated directly according to the data $[$ gamma $=0.445]$ ); (5) reliability for the internal branch was assessed by hiring aLRT test (SH-Like); and, (6) graphical representation and edition of the phylogenetic tree were performed using TreeDyn (v198.3) (Dereeper et al. 2008).

To study the character evolution (Fig. 2b), the sequences manually aligned via MUSCLE using MEGA software ver.7 (Kumar et al. 2016). Poorly aligned positions and divergent regions were eliminated by using Gblocks 0.91b, following the given options for less stringency (Castresana 2000). Phylogenetic analyses were performed using the combined 3-loci data set. The partitioned ML analysis was fulfilled using raxmlGUI 1.1 (Silvestro and Michalak 2012) under the GTR + G model with 1000 bootstrap replicates and with Asperugo (tribe Asprugeae) and Myosotis (tribe Myosotideae) chosen as out-groups. The evolutionary history of characters was traced over an ML tree in Mesquite 3.04 (Maddison and Maddison 2015). The ML approach was applied with the Markov k-state one-parameter (Mk1) model (Lewis 2001).

\section{Result}

\section{General description of nutlet micromorphology}

The nutlet's morphology and ultrastructure characteristics such as shape size, appendages, and surface sculpturing, varied among the studied taxa. The Rochelieae nutlets' shapes were different across samples; while some had ovoid shapes (ovoid, ovoid-triangular, and ovoid-rectangular), some other samples had pyramid shape (Fig. 1). In the out-groups, the shape of Asperugo procumbense was semicircular, and the Myosotis sylvatica was of ellipse shape. These two genera belong to Asperugeae and Myosotideae tribes, respectively.

Nine qualitative characters were selected for the morphological evaluation of nutlets. The results obtained from nutlet-ultrastructure investigations are described below and illustrated in Fig. 1. Generally, six different surface types were recognized among studied taxa based on nutlet ultrastructure characters: 
Type I: Heterocaryum and Pseudolappula (Syn: L. siniaca)

There was no glochid or appendage on the nutlet disk, but a row of glochid (Heterocaryum) or glochid-like (Pseudolappula) on the nutlet edge. The glochids were distributed sparsely on the edges of the nutlets of Pseudolappula. The nutlet disk ornament of Heterocaryum was "papilla verrucose with verrucae minutely muricate" (called complex papilla), the nutlet disk ornament of Pseudolappula was "papilla with aggregate verrucose in the center". It appeared that each of the microcapillaries found in Psudolappula were complex in the Heterocaryum, and each formed warts (verrucose), leading to a more complex and denser status.

\section{Type II: Lappula (L. barbata, L. microcarpa and L. semiglabra).}

Glochids in different sizes and rows can be seen at the nutlet edge and sometimes on the nutlet disk surface. Glochids had an anchor with 2-4 branches at the apex, and their surface was smooth. The ultrastructure of the nutlet emergencies was stellar-aculeate, and in some case the appendage, prickles, or tubercles could be seen (scattered or collected) on the surface of the nutlet disk and edge. The glochid stem was composed of fusiform cells, and there were tubercles with 2 to 5 mineralized spines on the stem. These tubercles were also present on the entire surface of the nutlet with a different distribution.

\section{Type III: Rochelia (R. disperma, R. sessiflora = L. sessiflora).}

The prickles were arranged in a stellate pattern and scattered throughout the surface of the nutlet. The surface of the prickles was not glossy and was of verrucose. The tubercles often had more than 2 spines, and the emergencies were stellar-aculeate (similar to type II). Nonetheless, the nutlet surface of $R$. sessiflora was similar to type II (presence of glochid on the nutlet edge). Moreover, the prickles and the accumulation of tubercles with more than 5 spines around each prickle shared more resemblance with type III.

\section{Type IV: L. ceratophora and L. spinocarpus}

There was not any glochid, tubercle, or prickles on the nutlet surface. The nutlet surface of $L$. ceratophora was not smooth, and the papilla appeared as verrucose-like. The ultrastructure of the nutlet in L. spinocarpus had a similar appearance to papilla with flowerlike verrucose. Also, the tubercles appeared as verrucose lacking any spines.

\section{Type V: Asperugo}

The nutlet surface lacked any glochid and prickles. Papilla appeared dome-shaped in different sizes, with verrucose at the base of it.

\section{Type VI: Myosotis}

The surface of the nutlet was smooth, and there was no ornamentation (nonexpressiate).

\section{Evolution of nutlet's microstructural characters}

We did not observe topological contradiction for the Rochelieae tribe in the analysis that were performed by constructing gene trees from the nr-DNA ITS, concatenated trnL-F-rpl32-trnL(UAG), and concatenated nrDNA ITS-trnL-F-rpl32-trnL(UAG) data sets. This was consistent with what was reported by KhoshsokhanMozaffar et al. (2018). Therefore, for preventing sloppiness, we selected nr-DNA ITS because of better resolution. Details of the ML analyses based on the nrDNA ITS data set confirmed the phylogenetic relationships of some species of Rochelieae and then formed a well-supported lineage encompassing two clades. This is totally in agreement with the topology published by Khoshsokhan-Mozaffar et al. (2018). One clade was composed of sub-tribe Heterocaryinae (HeterocaryumSuchtelenia), with high support $(\mathrm{BS}=0.99)$. The next

\footnotetext{
(See figure on next page.)

Fig. 1 Six types of nutlet morphology in the studied species. $\mathbf{a}-\mathbf{h}=$ Type $\mathbf{~ ; ~}(\mathbf{a}-\mathbf{d})$ Heterocaryum rigidum; $\mathbf{a}$, b: An overview photograph of nutlet with stereomicroscope and SEM. c, d: The close-up views of the nutlet disk with "papilla verrucose with verrucae minutely muricate". (e-h) Pseudolappula siniaca; $\mathbf{e}, \mathbf{f}$ : An overview photograph of nutlet with stereomicroscope and SEM. $\mathbf{g}$, h: The close-up views of the nutlet disk with "papilla with aggregate verrucose in the center". i-o Type II. (i, j) Lappula. barbata; (k, I) Lappula. Microcarpa; (The more detail of these two species were described between different specimens in Fig. 3). Lappula semiglabra m, n: An overview photograph of nutlet with stereomicroscope and SEM. o: The close-up views of the nutlet disk. $\mathbf{p}-\mathbf{v}=$ Type III; $(\mathbf{p}-\mathbf{r})$ Rochelia sessiflora; $\mathbf{p}$, q: An overview photograph of nutlet with stereomicroscope and SEM. r: The close-up views of the nutlet disk with prickles and verrucose on it. (s-v) Rochelia disperma s, t: An overview photograph of nutlet with stereomicroscope and SEM. $\mathbf{u}, \mathbf{v}$ : The close-up views of stellare-aculeate emergencies in nutlet disk. $\mathbf{w}$-ac = Type IV; ( $\mathbf{w}-\mathbf{y})$ Lappula spinocarpus; w, x: An overview photograph of nutlet with stereomicroscope and SEM. $\mathbf{y}$ : The close-up views of the nutlet disk with papilla with flowerlike verrucose on it. (z-ab) Lappula ceratophora z, aa: An overview photograph of nutlet with stereomicroscope and SEM. ab: The close-up views of the nutlet disk with papilla appear as a verrucose-like on it. ac-af =Type V; Asperugo procumbense; ac-ad: the overview photograph of nutlet with stereomicroscope and SEM. af: The close-up views of the nutlet disk with papilla appear as dome-shape on it. ag-aj=Type VI; Myosotis sylvatica; ag-ai: the overview photograph of nutlet with stereomicroscope and SEM. aj: The close-up views of the nutlet disk with a smooth surface
} 


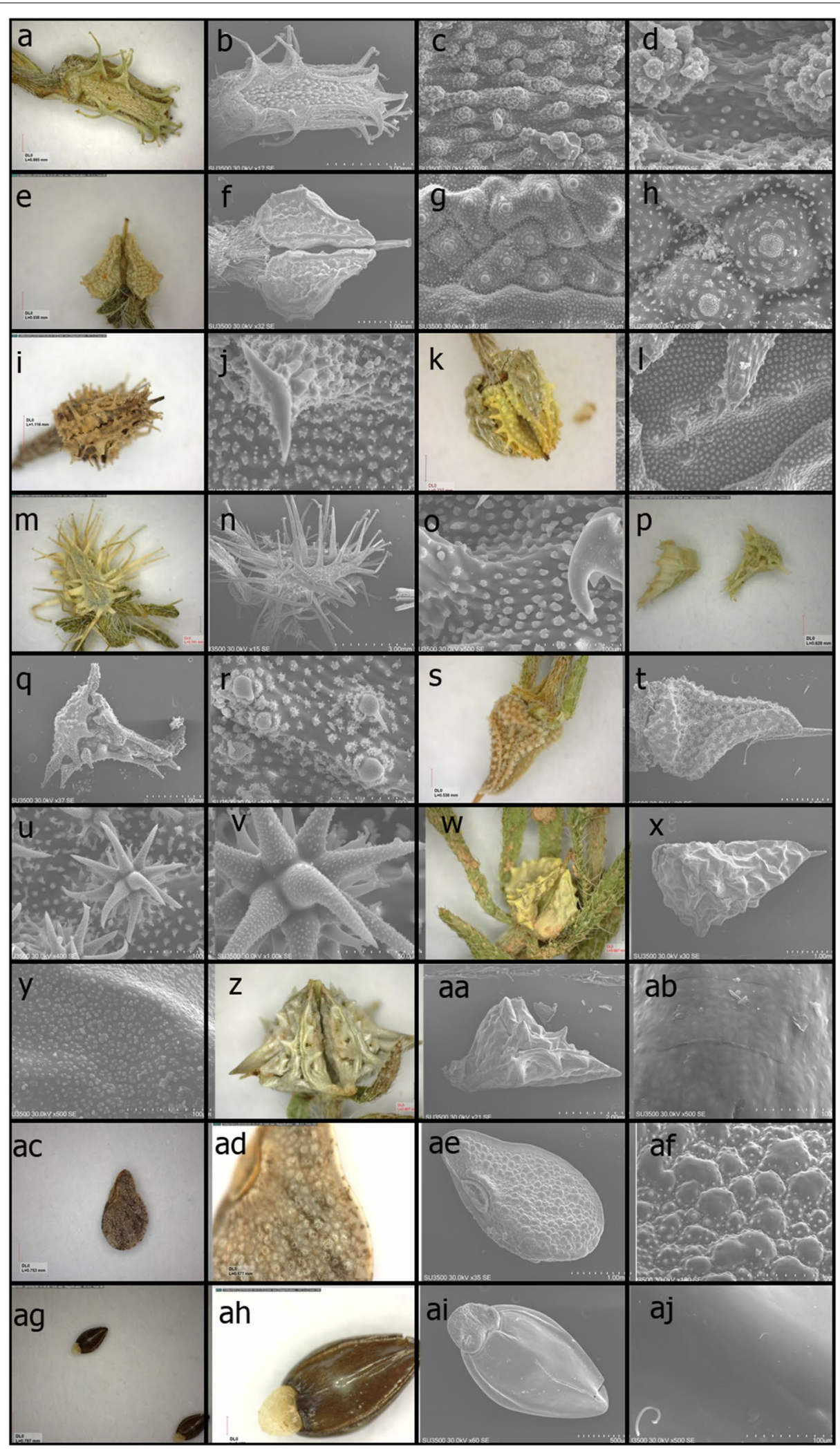

Fig. 1 (See legend on previous page.) 
clade contained most subtribe Eritrichiinae $(\mathrm{BS}=0.85)$ comprising Lappula, Eritrichium, Lepechiniella, Hackelia, and Rochelia. Within this clade, Lappula sinaica formed the distinct branch and nested far away from other Lappula species. Moreover, Lappula sessiliflora was nested with a subclade of Rochelia species (Fig. 2A).

The resulting ancestral state reconstruction and the proportional likelihoods for character states are shown in Fig. 2B. Two out-group species Asperugo and Myosotis were unique with the bilaterally flattened and ellipse with a smooth surface, respectively. Tracing the evolution of nutlet micromorphology indicated that the glochids are not an ancestral character.

\section{Arrangement of glochid character}

The status of ancestral taxa (with or without glochids) was unclear, and the proportional likelihoods of all three characters were almost equal (node A). Transition to the glochids character occurred in the genus Lappula ( $L$. semiglabra, L. microcarpa, and L. barbata) (node H).

\section{The appendage on nutlet disk character}

The status "without appendage" and "dump-shape papilla" in Myosotis and Asperugo (the proportional likelihood 1) differentiated these two tribes from each other and Rocheliea tribe. The tubercle and prickles on the disk were ancestral characters (the proportional likelihood $0.43)$. While the ancestor of these characters was unclear in node A, the status "tubercle and prickles on disk" was of more proportional likelihood in $\mathrm{A}$ and then $\mathrm{C}$, D, F group. Transition to the "lack of appendage" status occurred in the L. ceratophora, L. spinocarpus; node G).

\section{Prickles surface character}

Tracing of character "prickles surface" showed the ancestral status of "lack of prickles" in node A that to be followed with less proportionality in nodes B, C, and D. Transition to the "glossy prickles" status occurred in the genus Lappula in node $\mathrm{H}$. Moreover, the transition to the simple and complex "verrucose prickles" status was observed in genus Rochelia in node F.

\section{Surface emergence}

Tracing of surface emergence character was unclear in node A. Though, the proportional likelihoods of "stellaraculeate" status had the highest node $C$ ratio (0.72).
In node G, the transition to "verrucose-subverrucose" status (the proportional likelihoods 0.99) was stabilized as a synapomorphy.

Other traits were studied regarding evolutionary tracing that did not show clear evolutionary signals in the nodes, such as the shape of the nutlet, the lamella type, the shape of the nutlet, the lamella type, and the centerline of the nutlet disk.

\section{Close boundary of nutlet microstructures between $L$. barbata and L. microcarpa}

Both L. microcarpa and L.barbata had high micro-morphological similarities (Fig. 3). The very close relationship was studied by PCA analysis about other studied taxa in the tribe Rochelieae. In total, nine nutlet characteristics of the studied taxa were investigated (see nutlet SEM characters in Table 2). PCA analysis of nutlet characteristics revealed that the first two PCs comprised $75.83 \%$ of the total variability of the taxa. In the first PCA axis, characters such as the appendage on nutlet desk, shape of nutlet; surface emergence and prickles surface showed the highest correlation, while in the second PCA axis, other characters, such as seed shape of nutlet, tubercles on the desk and the centerline of nutlet showed the highest correlation. Therefore, these were the most varied micro-morphological characters of the taxa. PCA-biplot of micro-morphological characters (Fig. 4a) separated the taxa into distinct groups. All specimens of $L$. barbata and L. microcarpa were clustered together and close to L. semiglabra (Fig. 4a), while other taxa were grouped together. Moreover, L. ceratophora and L. spinocarpos overlapped each other.

Different clustering and ordination methods produced similar results; therefore, only the WARD tree of micromorphological characters is presented here (Fig. 4b). The taxa were separated in the WARD tree of micro-morphological features, subsequently resulted in main branches. One included three genera arranged in two sub-groups: subgroup I, including all specimens, which belonged to L.barbata and L.microcarpa, while L.semiglabra diverged from others and placed in sub-group II. The rest of the taxa were clustered with each other in the same branch, similar to the results of the PCA plot (Fig. 4a). This result implies that the micro-morphological characters could not delimit two species L. barbata and L.microcarpa.

(See figure on next page.)

Fig. 2 A Details of the ML tree of some species of Rochelieae showing the glancing view on phylogenetic relationships of different genera and species with focused on Lappula genus. The taxa selected for character evolution analysis were shown by an asteroid. B Results of nutlet character evolution are shown on the Maximum Likelihood tree of tribe Rochelieae (based on the internal transcribed spacer). Numbers on branches are Maximum Likelihood bootstrap support (only shown when $\geq 65$ ) 


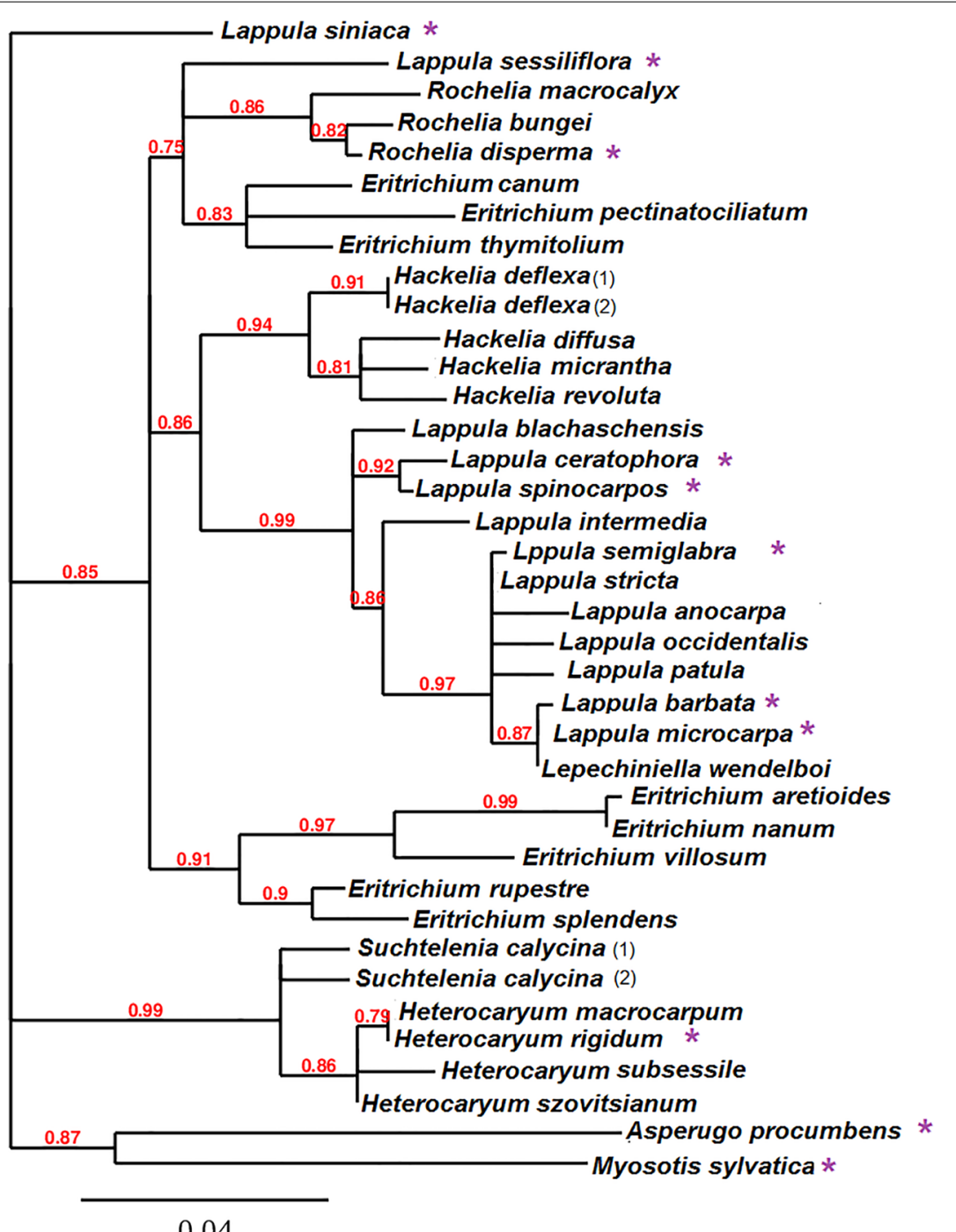

0.04
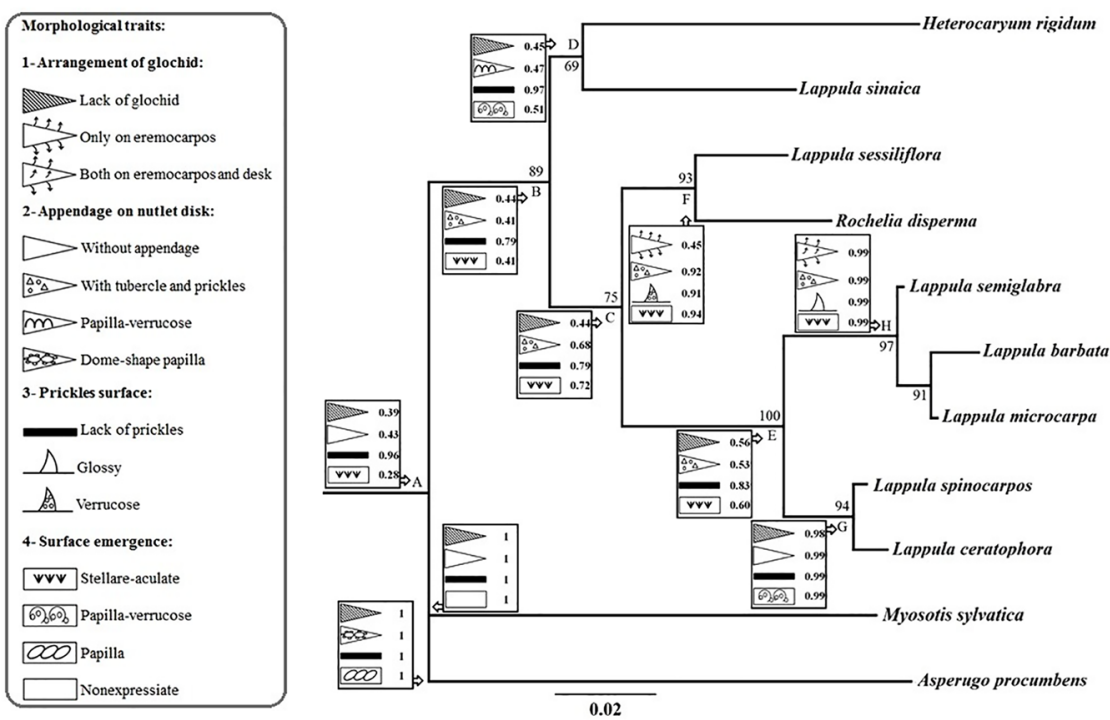

Fig. 2 (See legend on previous page.) 


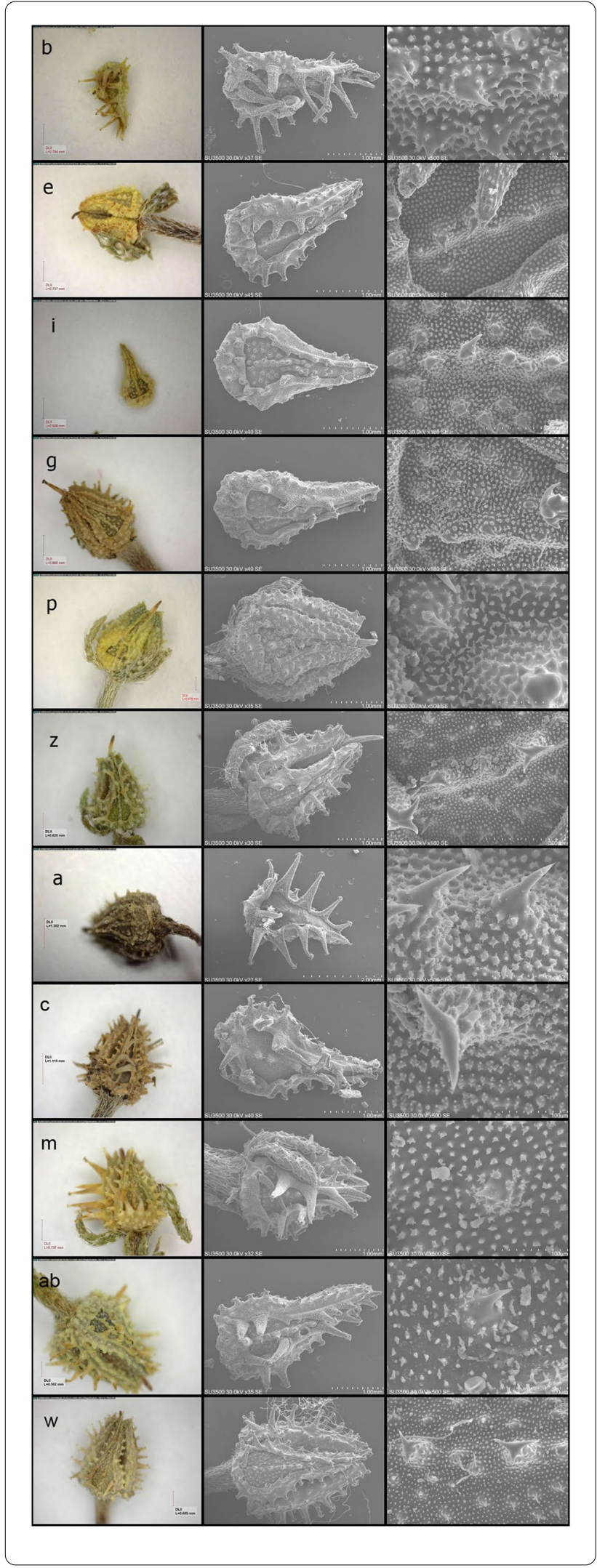

Fig. 3 nutlet morphology in the different specimens of Lappula microcarpa and lappula barbata. The details of the studied specimens are in accordance with Table 1 (L. microcarpa codes: b, e, I, g, p, z, a; L. barbata: $c, m, A b, w)$

\section{Discussion}

As in other Boraginaceae genera, the infrageneric taxonomic significance of nutlet characteristics in tribe Rochelieae were found to be evident through investigation employing stereomicroscope and SEM (Ovchinnikova 2009; Weigend et al. 2009; Selvi et al. 2011; Yu et al. 2012; Hilger 2014). In this study, we found that the appendages on the nutlet varied between different genera. Although the fruit type of Boraginaceae is relatively constant, the variation in nutlet ornamentation has quickly occurred in some tribes like Cynoglosseae sensu lato (including tribe Rocheliea) and Trichodesmeae (Cohen 2014).

It is not surprising that Lappula, one of the largest genera in Rochelieae, exhibits considerable diversity in nutlet characters. Recent molecular evidence suggested that Lappula is polyphyletic (Khoshsokhan-Mozaffar et al. 2018). In this regard, Khoshsokhan-Mozaffar et al. indicated that species of the Lappula genus are scattered across the Eritrichiinae clade and formed three distinct lineages. Lappula sinaica, as a new genus, was segregated from Lappula and established as genus Pseudolappula (Khoshsokhan-Mozaffar et al. 2018). Moreover, as shown in our study, a distinct generic delimitation based on nutlet characters alone could be detected for Pseudolappula (syn: Lappula siniaca). Nutlet micromorphology of Pseudolappula (syn: L. siniaca) provides valuable data in favor of separating it from Lappula genus; so that, the characters are "no glochid or appendage on nutlet disk" and the type of nutlet ornamentation including "papilla with aggregate verrucose in the center". The features of disk ornamentation indicated a more close affinity of Pseudolappula siniaca to Heterocaryum than Lappula genus, especially in the evolution of microcapillaries. Current data are also in accordance with molecular phylogenies provided by (Khoshsokhan-Mozaffar et al. 2018) that transferred closely related species $L$. sessiliflora to Rochelia genus. This conclusion has previously been suggested by various studies (Khoush et al. 2010; Huang et al. 2013; Mozaffar et al. 2013; Rolfsmeier 2013; Weigend et al. 2013). Moreover, the flowers and nutlet features (two of them undeveloped) designated more affinity of the species to Rochelia genus than Lappula (Popov 1974). Our result stipulated the features like prickles and verrucose on the nutlet, and the accumulation of tubercles with more than five spines around each prickle showed more similarity to genus Rochelia. 


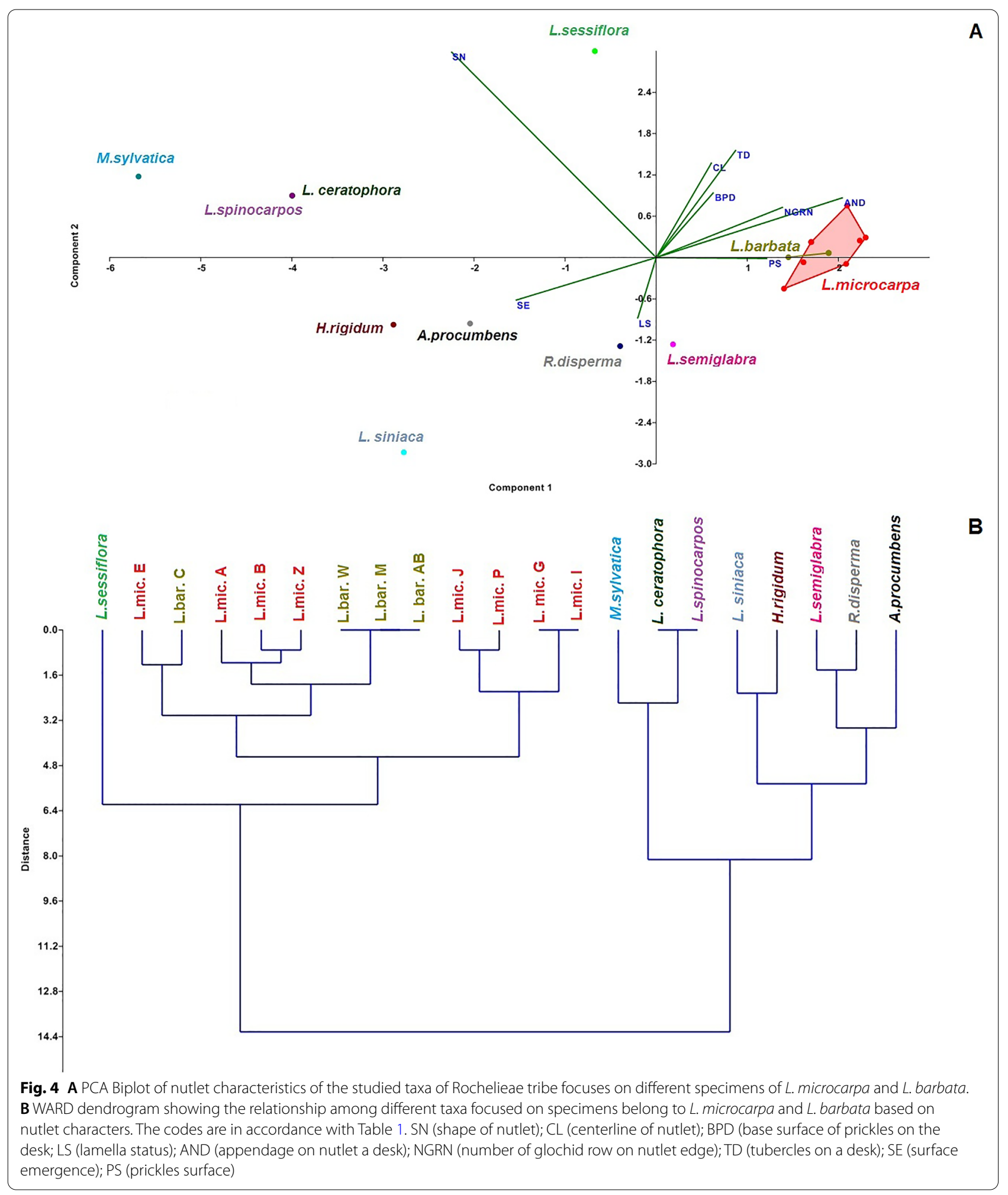

The present study convincingly provided a clear distinction between two species L. ceratophora and L. spinocarpus, which belong to sect. Sclerocaryum (Riedl 1967;
Ovchinnikova 2009), from other Lappula genus. The lack of glochid, tubercle, or prickles on the nutlet surface and specific types of nutlet ornamentation (papilla with 
verrucose-like or flowerlike-verrucose) characterized the clade that includes them regarding recent molecular phylogenetic analysis (Khoshsokhan-Mozaffar et al. 2018).

We identified four different types of nutlet surface ornamentation among taxa. According to our study and reported by others (Cohen 2014), the ancestral type is ambiguous for the family and Rochelieae tribe. Given the matrix of cpDNA-nr-DNA ITS and nutlet surface analysis, (Cohen 2014) indicated the smooth nutlets as ancestral for the clade that includes Boragineae and Lithospermeae tribes, and nutlets with glochids as a synapomorphy for Cynoglosseae sensu lato (including tribe Rocheliea). The results of the current study are in agreement with Cohen (2014) who demonstrated that glochid is not an ancestral trait but is a synapomorphy so that in node $\mathrm{H}$, the transition trait occurred in the genus Lappula. Rocheliae is characterized by a transition from "without appendage" to "with tubercles and prickles" on the nutlet disk, and also by a shift from "lack of prickles" to "glossy prickles". Also, a transition from the "nonexpressiate" status of surface emergence to "stellaraculeate" status occurred in this tribe. Interestingly, in this tribe, smooth nutlets were a synapomorphy (Cohen 2014). Considering this, the transition to "lack of appendage" occurred in node G could indicate a synapomorphy of two species of sect. Sclerocaryum (L. ceratophora and L. spinocarpus).

In Boraginaceae, nutlets need to develop strategies to achieve dispersal ability. In previous studies, nutlets with glochids or wings have implied adaptive traits for additional dispersal types, such as epizoochory or anemochory (Ma et al. 2010; Selvi et al. 2011). The presence of glochid on the nutlet could explain the widespread geographic distribution of Cynoglosseae sensu lato (including Rochelieae) (Cohen 2014). According to (Weigend et al. 2016), two species of sect. Sclerocaryum applies "the whole-plant dispersal by wind or flash-floods" as a dispersal mechanism which could explicate the synapomorphy of "lack of appendage" observed in our results. Indeed, this mechanism caused the separation of nutlets from the mother plant to become unnecessary.

Morphologically, Rochelieae is characterized by divided calyx toward its base, hypocrateriform to infundibuliform corolla, pyramidal to subulate gynobase with 1-4 nutlets (Riedl 1967, Popov 1974, Chacón et al. 2016). However, Lappula species have blue to white funnel-form to campanulate corollas and form a scorpioid cymose inflorescence. In this genus, there are four homomorphic (sometimes heteromorphic) nutlets with one or more rows of marginal spines/glochidia (Riedl 1967, Popov 1974, Weigend et al. 2016). Morphometric results based on the nutlet morphology indicated four essential points, including the close affiliation of $L$. sessiflora to
Rochelia than to the Lappula genus, the narrow barriers between L.barbata and L.microcarpa, and the apparent distinction of L.siniaca from other Lappula species. More affinity of L.sessiflora to Rochelia genus was proposed by Popov (1974), followed by different molecular phylogeny studies that finally ranked it as Rochelia species (Khoshsokhan-Mozaffar et al. 2018). Four zygomorphous and unequal nutlets were interpreted as diagnostic features of the Heterocaryum. These nutlets are small, flat, dorsiventrally compressed, with dentate wings (Khoshsokhan-Mozaffar et al. 2018). Although in the phylogenetic tree, the Heterocaryum genus did not indicate the close affinity to Lappula siniaca, morphometric results showed more similarity to Heterocaryum than other Lappula species. Based on morphometric results, Lappula spinocarpos and L. ceratophora (both of the sect. Sclerocaryum) were closely located to each other that showed more affinity to Myosotis and were apart from other Lappula species. These two species have nutlets with uniform, thick, and stonelike tubercles, with almost smooth surface. Although these two species have experienced different taxonomic treatment and have often been identified as distinct genus [Sclerocaryopsis; Sadat (1989)], recent morphological and molecular studies have identified them as members of the genus Lappula (Nasir 1989; Khatamsaz 2002; Chacón et al. 2016; KhoshsokhanMozaffar et al. 2018).

Nutlet micromorphology results did not show clear distinction among species L.barbata and L. microcarpa. The morphological complexities of these two species have already been addressed by different taxonomists (Popov 1953; Akhani 1998). A revision of the Lappula genus by (Nasseh and Joharchi 2017) suggested that the two species may be synonymous and further molecular studies need to conduct. Moreover, according to the molecular results (Khoshsokhan-Mozaffar et al. 2018) in the nrDNA ITS tree of Rochelieae, the clade delimiting these two species was not well-supported. All of this evidence and our results convinced us to consider all specimens belong to L.barbata and L.microcarpa as "complex species" including L.mocrocarpa, L.barbata, L.semiglabra that could be comparable with L.wendelboi. Recently, Lepechiniella wendelboi Riedl was considered as a synonym of Lappula wendelboi (Riedl) Khoshsokhan \& Kaz. Osaloo, based on molecular analysis (KhoshsokhanMozaffar et al. 2018). According to the literature, the three Lepechiniella species (L. albiflora, L. persica and $L$. wendelboi) were transformed to Lappula genus because of morphological and molecular similarities.

A supplementary molecular study and nutlet micro/ macromorphology in different geographical regions is needed to synonym L. barbata and L.microcarpa or any taxonomical treatment. 
The variety observed in the nutlet of L.microcarpa and L.barbata could be related to seed heteromorphism that formerly is known to occur in a few Boraginaceae genera, e.g. Eritrichium, Lappula (L. duplicicarpa and L. semiglabra), and Heterocaryum (Wang et al. 1989). In species with heteromorphic seeds, the variations in shape, color, size, or associated structures (wings or bracts) could be a strategy for flexibility in modes of dispersal, dormancy, and timing of germination. This could be helpful regarding the seedling establishment in arid regions (McEvoy 1984; Imbert 2002; Evans et al. 2007; Venable 2007; Sun et al. 2008; Wang et al. 2008). Zhao et al. (2008) reported that Lappula duplicicarpa and L. semiglabra have heteromorphism nutlets with long and short glochids. Given the close relativity of L.semiglabra to L.barbata and L.microcarpa, it is recommended that future studies focus further on the nutlet heteromorphism.

\section{Conclusions}

In this study, the nutlet ultrastructure pattern of Rochelieae was systematically informative at the genus level, but not at the species level. The results showed that glochid is not an ancestral trait but is a synapomorphy and the transition to this trait occurred in the genus Lappula. Nutlet micromorphology results in this study provided no clear distinction between species L.barbata and L. microcarpa.

\section{Acknowledgements}

The authors wish to thank Saeed Javadi Anaghizi in the Central laboratory of the Shahid Beheshti University for providing SEM pictures. We thank Dr. Somayeh Naghiloo (University of Calgary, Canada) for assisting in software analysis. We also thank Sebastien Santini (CNRS/AMU IGS UMR7256) and the PACA Bio info platform (supported by IBISA) for the availability and management of the phylogeny.fr website.

\section{Authors' contributions}

SN designed the study project, ME \& SN performed experiments and data analysis, and drafted the manuscript. All authors read and approved the final manuscript.

\section{Funding}

This research received no specific grant.

\section{Availability of data and materials}

The data used and analyzed for the current study can be obtained from the corresponding author.

\section{Declarations}

Ethics approval and consent to participate

Not applicable.

\section{Consent for publication}

Not applicable.

\section{Competing interests}

The authors declare that they have no competing interests.

\section{Author details}

${ }^{1}$ Department of Biology, Faculty of Sciences, Azarbaijan Shahid Madani University, 53714-161 Tabriz, Iran. ${ }^{2}$ Faculty of Life Sciences \& Biotechnology, Shahid Beheshti University, Tehran, Iran.

Received: 12 May 2021 Accepted: 12 October 2021

Published online: 24 October 2021

\section{References}

Akçin Ö (2007) Nutlets micromorphology of some Onosoma L. (Boraginaceae) species from Turkey. Biologia 62:684-689

Akçin OE (2008) Seed coat and fruit surface micromorphology of some Cynoglossum L. (Boraginaceae) species. Bangladesh J Plant Taxon 37:115-119

Akhani H (1998) Plant biodiversity of Golestan National Park. Biologiezentrum des OÖ Landesmuseums, Iran

Al-Shehbaz IA (1991) The genera of Boraginaceae in the southeastern United States. J Arnold Arboretum Suppl Ser 1:1-169

Binzet R, Akçin ÖE (2009) Nutlet size, shape and surface ornamentation in 14 Onosma species (Boraginaceae). Acta Bot Croat 68:117-126

Boyd A (2002) Morphological analysis of Sky Island populations of Macromeria viridiflora (Boraginaceae). Syst Bot 27:116-126

De Candolle A (1845) Prodromus Systematis naturalis regni vegetabilis, Paris

Castresana J (2000) Selection of conserved blocks from multiple alignments for their use in phylogenetic analysis. Mol Biol Evol 17:540-552

Chacón J, Luebert F, Hilger HH, Ovchinnikova S, Selvi F, Cecchi L, Guilliams CM, Hasenstab-Lehman K, Sutorý K, Simpson MG (2016) The borage family (Boraginaceae s. str.): a revised infrafamilial classification based on new phylogenetic evidence, with emphasis on the placement of some enigmatic genera. Taxon 65:523-546

Cohen II (2014) A phylogenetic analysis of morphological and molecular characters of Boraginaceae: evolutionary relationships, taxonomy, and patterns of character evolution. Cladistics 30:139-169

Dereeper A, Guignon V, Blanc G, Audic S, Buffet S, Chevenet F, Dufayard JF, Guindon S, Lefort V, Lescot M (2008) Phylogeny. fr: robust phylogenetic analysis for the non-specialist. Nucleic Acids Res 36:465-469

Evans ME, Ferriere R, Kane MJ, Venable DL (2007) Bet hedging via seed banking in desert evening primroses (Oenothera, Onagraceae): demographic evidence from natural populations. Am Nat 169:184-194

Gottschling M, Luebert F, Hilger HH, Miller JS (2014) Molecular delimitations in the Ehretiaceae (Boraginales). Mol Phylogenet Evol 72:1-6

Hilger HH (2014) Ontogeny, morphology, and systematic significance of glochidiate and winged fruits of Cynoglosseae and Eritrichieae (Boraginaceae). Plant Divers Evol 131:167-214

Hilger H (1985) Ontogenie, Morphologie und systematische Bedeutung geflugelter und glochidientragender Cynoglosseae-und EritricheaeFruchte (Boraginaceae). Bot Jahrb Syst, Pflanzengesch Pflanzengeogr

Huang JF, Zhang ML, Cohen JI (2013) Phylogenetic analysis of Lappula Moench (Boraginaceae) based on molecular and morphological data. Plant Syst Evol 299:913-926

Imbert E (2002) Ecological consequences and ontogeny of seed heteromorphism. Perspect Plant Ecol Evol Syst 5:13-36

Johnston I (1937) Studies in the Boraginaceae XII. 2. Novelties and critical notes. J Arnold Arbor 18:10-25

Kahraman A, Celep F, Doğan M, Guerin GR, Bagherpour S (2011) Mericarp morphology and its systematic implications for the genus Salvia L. section Hymenosphace Benth. (Lamiaceae) in Turkey. Plant Syst Evol 292:33-39

Khatamsaz M (2002) Flora of Iran, vol 39. Research Institute of Forests and Rangelands, Tehran (In Persian)

Khoshsokhan-Mozaffar M, Sherafati M, Kazempour-Osaloo S (2018) Molecular phylogeny of the tribe Rochelieae (Boraginaceae, Cynoglossoideae) with special reference to Lappula. Ann Bot Fenn BioOne 293-308

Khoush SMM, Kazempour OS, Saadatmand S, Atar F (2010) Molecular phylogeny of Rochelia (Boraginaceae) based on nrDNA ITS and cpDNA trnL-F sequences, pp 22-29

Kumar S, Stecher G, Tamura K (2016) MEGA7: molecular evolutionary genetics analysis version 7.0 for bigger datasets. Mol Biol Evol 33:1870-1874

Långström E, Chase M (2002) Tribes of Boraginoideae (Boraginaceae) and placement of Antiphytum, Echiochilon, Ogastemma and Sericostoma: a 
phylogenetic analysis based on atpB plastid DNA sequence data. Plant Syst Evol 234:137-153

Lehmann JGC (1818) Plantae e familia Asperifoliarum nuciferae. Dummler, Berlin, $\mathrm{p} 78$

Lewis PO (2001) A likelihood approach to estimating phylogeny from discrete morphological character data. Syst Biol 50:913-925

Ma W, Zhao X, Tan D, Baskin C, Baskin J, Xue J (2010) Nutlet dimorphism in individual flowers of two cold desert annual Lappula species (Boraginaceae): implications for escape by offspring in time and space. Plant Ecol 209:361-374

Maddison W, Maddison D (2015) Mesquite: a modular system for evolutionary analysis. Version 3(04):2015

McEvoy PB (1984) Dormancy and dispersal in dimorphic achenes of tansy ragwort, Senecio jacobaea L. (Compositae). Oecologia 61:160-168

Moon HK, Hong SP (2006) Nutlet morphology and anatomy of the genus Lycopus (Lamiaceae: Mentheae). J Plant Res 119:633-644

Mozaffar MK, Osaloo SK, Oskoueiyan R, Saffar KN, Amirahmadi A (2013) Tribe Eritrichieae (Boraginaceae s. str.) in West Asia: a molecular phylogenetic perspective. Plant Syst Evol 299:197-208

Nasir YJ (1989) Flora of Pakistan, vol 191. University of Karachi, Karachi

Nasseh Y, Joharchi MR (2017) Revision of the genus Lappula Moench based on morphological characters in Khorassan Provinces (Iran). Nova Biol Rep 4:66-73

Ovchinnikova S (2005) The system of the subtribe Echinosperminae (Boraginaceae). Bot Zhurn 90:1153-1172

Ovchinnikova S (2009) On the position of the tribe Eritrichieae in the Boraginaceae system. Bot Serbica 33:141-146

Ovchinnikova S (2008) Conspectus of the genus Eritrichium (Boraginaceae) species in North Asia. Rastitel'n Mir Aziatsk Rossii [= PI. Life Asian Russia] 1:17-36

Ovczinnikova S (2007) The system of the tribe Eritrichieae (Boraginaceae). Bot Zhurn 92:751-759

Popov M (1953) Boraginaceae. Flora SSSR 19:97-691

Popov MG (1974) Boraginaceae. In: Shishkin BK (ed.), Flora of the USSR, vol. 19 [English translation]: 73-531. Israel Program for Scientific Translations, Jerusalem

Riedl H (1967) Boraginaceae in, Rechinger KH. Flora Iranica. Graz, Akademische Druck_u. Verlagdanstalt 48:215

Riedl H (1996) Studies in the genus Lappula (Boraginaceae) I. Lappula in the" Flora Iranica" region. Serie B für Botanik und Zoologie. Ann Naturhist Mus 79-86

Rolfsmeier SJ (2013) Taxonomy and phylogeny of the genus Lappula Moench (Boraginaceae) in North America. Kansas State University.
Saadati N, Mozaffar MK, Sherafati M, Osaloo SK (2017) Pseudoheterocaryum, a new genus segregated from Heterocaryum (Boraginaceae) on the basis of molecular data. Aust Syst Bot 30:105-111

Selvi F, Bigazzi M, Hilger HH, Papini A (2006) Molecular phylogeny, morphology and taxonomic re-circumscription of the generic complex Nonea/Elizaldia/Pulmonaria/Paraskevia (Boraginaceae-Boragineae). Taxon 55:907-918

Selvi F, Coppi A, Cecchi L (2011) High epizoochorous specialization and low DNA sequence divergence in Mediterranean Cynoglossum (Boraginaceae): evidence from fruit traits and ITS region. Taxon 60:969-985

Silvestro D, Michalak I (2012) raxmIGUI: a graphical front-end for RAxML. Org Divers Evol 12:335-337

Sun H, Tan D, Qu R (2008) Characteristics of heteromorphic achenes of Garhadiolus papposus, an ephemeral Asteraceae species, with reference to their adaptations to desert environment. Biodivers Sci 16:353

Venable DL (2007) Bet hedging in a guild of desert annuals. Ecol 88:1086-1090

Wang WC, Liu YL, Zhu GL, Lian YSh, Wang JQ, Wang QR (1989) Lappula V. Wolf. In: Kong XW, Wang WC (eds) Flora Reipublicae Popularis Sinicae, vol 64. Science Press, Beijing, pp 177-207 (in Chinese)

Wang L, Huang Z, Baskin CC, Baskin JM, Dong M (2008) Germination of dimorphic seeds of the desert annual halophyte Suaeda aralocaspica (Chenopodiaceae), a C4 plant without Kranz anatomy. Annal Bot 102:757-769

Weigend M, Gottschling M, Selvi F, Hilger HH (2009) Marbleseeds are gromwells_-systematics and evolution of Lithospermum and allies (Boraginaceae tribe Lithospermeae) based on molecular and morphological data. Mol Phylogenetics Evol 52:755-768

Weigend M, Luebert F, Selvi F, Brokamp G, Hilger HH (2013) Multiple origins for Hound's tongues (Cynoglossum L.) and Navel seeds (Omphalodes Mill.) - the phylogeny of the borage family (Boraginaceae s. str.). Mol Phylogenetics Evol 68:604-618

Weigend M, Selvi F, Thomas D, Hilger H (2016) Boraginaceae. Flowering Plants. Eudicots. Springer, pp. 41-102

Yu WT, Jacques FM, Chen ST, Zhou ZK (2012) Nutlet micro-morphology of the genus Microula (Boraginaceae) from the Qinghai-Tibetan Plateau, and its systematic implications. Nord J Bot 30:596-612

Zhao X, Tan D, Li X (2008) The breeding system of two ephemeral species of Lappula, with reference to their adaptations to the Junggar Desert environment, northwest China. J Desert Res 28:294-300

\section{Publisher's Note}

Springer Nature remains neutral with regard to jurisdictional claims in published maps and institutional affiliations.

\section{Submit your manuscript to a SpringerOpen ${ }^{\circ}$ journal and benefit from:}

- Convenient online submission

- Rigorous peer review

- Open access: articles freely available online

- High visibility within the field

- Retaining the copyright to your article

Submit your next manuscript at $\boldsymbol{\Delta}$ springeropen.com 